\title{
Proceeding
}

Supplementary Issue: Winter Conferences of Sports Science. International Conference of Engineering, Innovation Technology and Applied Science.

\section{Development of the level of formation of managerial competence at the future pedagogues of physical culture in the aspect of comparative analysis}

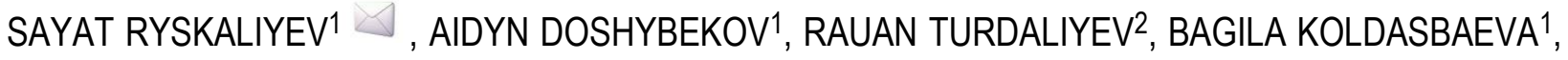 \\ ZURA KHAKIMOVA ${ }^{1}$ \\ ${ }^{1}$ Kazakh Academy of Sport and Tourism, Almaty, Kazakhstan \\ ${ }^{2}$ West-Kazakhstan Innovative-Technological University, Uralsk, Kazakhstan
}

\begin{abstract}
An article reveals the content of the concepts of "management", "managerial competence" and describes results of the experimental study on determination of the baseline level of formation of managerial competence at future teachers of physical culture. During the research, there was applied such method as analysis of the basic concepts based on the study of philosophical, psychological-pedagogical, sociological, special literature, normative documents and analytical materials of the Ministry of Education and Science of the Republic of Kazakhstan; the synthesis and interpretation of scientific data and experiment were carried out. The works of V. Sinyavsky and B.A. Fedorishin were the basis for use of the diagnostic instrumentation "Methodology for assessing the communicative and organizational abilities of the personality" on determination of the real state of formation of managerial competence at students. Two universities participated in the ascertaining experiment: West-Kazakhstan InnovativeTechnological University (WKITU) and Kazakh Academy of Sport and Tourism (KAST), where students in the specialty "Physical culture and sport", in the total number of 64 people, were involved. Thanks to the results of the ascertaining experiment, it was revealed that the process of formation of managerial competence at future teachers of physical culture corresponds to the level below the average. The following works were carried out in the research process: the essence of the concepts of "management", "managerial competence" was justified on the basis of the analysis of scientific psychological-pedagogical and special literature; the meaning of concept "managerial competence" was clarified; the experimental work on determination of the level of managerial competence at future teachers of physical culture was carried out. According to this research, the authors tried to determine the content of the concepts of "management", "managerial competence" and, for the first time, to identify the real state of the level of managerial competence at future teachers of physical culture; as well as the authors proposed their methodological recommendations for their further integration into the learning process.
\end{abstract}

Keywords: Management; Managerial competence; Future teacher of physical culture; Diagnostics; Levels of formation; Managerial ability; Communicative ability.

Cite this article as:

Ryskaliyev, S., Doshybekov, A., Turdaliyev, R., Koldasbaeva, B., \& Khakimova, Z. (2020). Development of the level of formation of managerial competence at the future pedagogues of physical culture in the aspect of comparative analysis. Journal of Human Sport and Exercise, 15(2proc), S444-S452. doi:https://doi.org/10.14198//hse.2020.15.Proc2.35

Corresponding author. Kazakh Academy of Sport and Tourism, 85 Abay ave., Almaty, 050022, the Republic of Kazakhstan.

E-mail: sayat813@gmail.com

Supplementary Issue: Winter Conferences of Sports Science. International Conference of Engineering, Innovation Technology and Applied Science.

JOURNAL OF HUMAN SPORT \& EXERCISE ISSN 1988-5202

(c) Faculty of Education. University of Alicante

doi:10.14198/jhse.2020.15.Proc2.35

S444

| 2020 | Proc2 | VOLUME 15

C 2020 University of Alicante 


\section{INTRODUCTION}

In the modern conditions of accelerated socio-economic development of our country it becomes necessary to increase competence, initiative, creativity, innovative activity of different categories of workers in organizations (enterprises, firms, institutions) of different sectors. In this regard, the role and importance of competent targeted management of personnel, people in all sectors of the economy and social sphere are increased.

At the same time, improving the training of highly qualified personnel in the field of physical culture and sports is the task of great social importance. The particular importance has the managerial training, since in the present stage of development society is urgently needed of specialists who are able to make responsible independent decisions, to organize their professional activities competently; who are able to lead others, i.e. who have managerial competence.

The research purpose is to disclose the content of concepts of "management", "managerial competence" and to describe the results of the experimental study on determination of the baseline level of formation of managerial competence at future teachers of physical culture.

\section{METHODS}

analysis of the basic concepts based on the study of philosophical, psychological-pedagogical, sociological, special literature, normative documents and analytical materials of the Ministry of Education and Science of the Republic of Kazakhstan; the synthesis and interpretation of scientific data and experiment. Two universities participated in the ascertaining experiment: West-Kazakhstan Innovative-Technological University (Uralsk city) and Kazakh Academy of Sport and Tourism (Almaty city), where students in the specialty "Physical culture and sport", in the total number of 64 people, were involved.

The methodological basis was the personality-oriented approach, which implies the desire to identify and form the unique human individuality, to develop own style of activity, to develop the best features and to neutralize negative manifestations. This requires the rejection of the gross, averaged approach to training and education, the elimination of bureaucratic style of management that suppresses the personality, the creation of conditions for the maximum manifestation of managerial abilities of the personality, originality in decision-making.

\section{RESULTS}

Managerial competence of specialists, graduated from higher educational institutions in physical culture, is an integral part of their professional competence, as all graduates of physical education university act as subjects of management of different links of physical education-sports movement and they perform functions of management of different scales and in different divisions.

The significant part of specialists immediately after graduating from the Institute of Physical Culture becomes managers of middle level (senior trainers, etc.) and directly managers (as directors of Children and Youth Sports School, chairmen of sports committees, heads of sports clubs, cooperatives, etc.). All of them, basically, rely on the store of knowledge of managerial competence that they acquired in the process of training at the institute. However, the current qualification characteristics of the profession, in our opinion, 
determine only the main content and organization of the training process of the specialist, without covering the whole spectrum of activities in this social need.

Researches testify that the ability to act confidently, energetically and creatively requires emotional maturity, which can be defined as the ability to meet acute situations, to deal effectively with them, not to worry about their actions and to know how to improve them next time.

The conception of "management" was originally defined as the continuous and focused process of influencing the collective of people to organize and coordinate their activities in the production process in order to achieve the best results at the lowest cost. In recent years, the term "management" has become fairly common in pedagogical science. However, it has various definitions.

Researcher-scientist Pavlova L.N. defines the concept of "pedagogical management" as the purposeful pedagogical impact with the aim of qualitative changes of the student team, characterized by the directivity on the development of the personality of each student. The pedagogical management, in its content, includes goal-setting, designing the control actions and their implementation (Pavlova, 2008). Thus, pedagogical management is the manifestation of the managerial competence of the pedagogue.

The most generalized classification of management functions is given by V.G. Afanasyev, who believes that the main functions, arising from the management cycle, are: the development and adoption of management decisions, organization, regulation, correction, accounting and control. The author specifies that the function of collecting and converting information corresponds to all stages, without exception, of the whole management cycle in general (Afanasyev, 1973).

The same algorithm is followed by B.F. Lomov, A.L. Zhuravlev, who highlight in the structure of the manager's activity the following series of actions corresponding to the main stages of its activity: long-term, short-term and operational planning, orientation in the situation and its diagnosis (assessment), the development and adoption of decisions, prognostication of expected results, organization of implementation of the program of made decisions, control, assessment and correction of results (Lomov et al., 1977; Zhuravlev, 2002).

It is generally accepted that the manager or leader must possess a number of undisputed qualities: firstly, knowledge of the science of management (theory and practice); secondly, to have the high overall level of development (ability to understand the essence of concepts and programmes, to conduct analysis, to be able to clearly state their thoughts); thirdly, to have confidence in his own strengths (including rigidity, self-control, assertiveness); fourthly, to be communicative, to understand well the characters and behaviour of people; fifthly, to have the ability to bring the case to the intended end, to the desired results.

M. Woodcock and D. Francis highlight the need for managers to have the following skills and abilities in modern conditions: the ability to manage themselves; reasonable personal values; clear personal goals; emphasis on continuous personal growth; problem solving skills; ingenuity and ability to innovate; high ability to influence others; knowledge of modern management approaches; ability to lead; ability to train and develop subordinates; ability to form and develop effective working groups (Woodcock \& Francis, 1991).

The special importance of the ability of managers to influence people and the ability to create effective groups is indicated by almost all researchers and specialists. The recognized manager of the last century, Lee Yakocca, in his famous book, speaks quite convincingly that all economic operations can ultimately be 
reduced to the designation of three words: people, product, profit. "If there is no reliable team, there can be done little from the other factors". Apparently, it cannot be said better about this (Ackerman, 1984).

This position is strongly supported by all modern domestic researchers. So, for example, L.B. Sulpovar and R.G. Mannapov added to the important qualities of the manager as "the ability to lead multidimensional, multifunctional groups and to participate constructively in their work" (Sulpovar \& Mazayeva, 996).

But along with this, it is very valuable to train your team to act independently. According to foreign researchers, the task of the management is not so much to identify and solve problems, but to create the environment in which people themselves can identify and solve their problems (Albrecht \& Zemke, 1985). For this, leadership must have the clear idea of where it leads the organization and the strengths to bring it to the purpose. Such conception has the great, if not the greatest impact, on organizational culture (Blake \& Mouton, 1964).

Together with it, the great importance is attached to the creation of the favourable environment in the organization, in this regard, it is emphasized that "the main advantage of the good manager is the ability to identify what is necessary for the development of production processes, and then to select and implement initiatives which will certainly help to create the productive working environment" (Lee, 1991). For this purpose, the manager must have analytical, organizational, psychological, creative abilities. There is important the high personal efficiency of the manager, based on good health, physical state, correct lifestyle, stable mental state.

At the same time, emotions which are recognized and should be characteristic of the manager (and the reasons why they consider them useful and positive) include the following: a) excitement: because it stimulates activity; b) empathy: because it makes management to be humane; c) interest: as it helps to move forward; d) curiosity: because it helps to master new spheres; e) confidence: as it adds solidity and grace to the efforts of the employees (Woodcock \& Francis, 1991).

Then, we tried to reveal the essence of the categories "management" and "managerial competence" on the basis of content-analysis (Table 1).

Table 1. Content-analysis of the concepts of "management" and "managerial competence" in the works of foreign and Kazakh researchers (1991-2014).

\begin{tabular}{|c|c|c|c|}
\hline No & Authors & Definition & References \\
\hline & \multicolumn{3}{|l|}{ Management } \\
\hline 1 & Group of authors & $\begin{array}{l}\text { Management - is maintenance in the specified } \\
\text { mode of activity with preservation of the certain } \\
\text { structure of different environment (social, } \\
\text { biological, technical) }\end{array}$ & $\begin{array}{l}\text { National Encyclopaedia of } \\
\text { Kazakhstan } \\
\text { Almaty, } 1999 \\
\text { Volume } 2, \text { p. } 720, \text { p.164 } \\
\end{array}$ \\
\hline 2 & T.I. Shamova & $\begin{array}{l}\text { She considers management as the active } \\
\text { interaction between the leaders of the } \\
\text { educational institution and other participants in } \\
\text { the educational process in ordering it and } \\
\text { transferring it to the new qualitative state that is } \\
\text { more consistent with the fulfilment of the set } \\
\text { tasks. }\end{array}$ & $\begin{array}{l}\text { Management in school } \\
\text { management: educational } \\
\text { manual for audience of the } \\
\text { system of QR (qualification } \\
\text { retraining) for education } \\
\text { organizers / M.: 1995. } 226 \text { p. }\end{array}$ \\
\hline
\end{tabular}




\begin{tabular}{|c|c|c|c|}
\hline 3 & V.A. Slastyonin & $\begin{array}{l}\text { Management is the activity, aimed at } \\
\text { development of the solution, organization, } \\
\text { control, regulation of the object of management } \\
\text { in accordance with the given goal, analysis and } \\
\text { summing up of results on the basis of reliable } \\
\text { information }\end{array}$ & $\begin{array}{l}\text { Pedagogy: innovative activity. } \\
\text { M., 1997-220 p. }\end{array}$ \\
\hline 4 & G. Atamanchuk & $\begin{array}{l}\text { Management is the goal-setting, that is, the } \\
\text { creative, thoughtful, organizing and regulating } \\
\text { influence of people on their own social activity, } \\
\text { which can be carried out both directly (in the } \\
\text { form of self-management) and through the } \\
\text { specially created bodies and structures (state } \\
\text { bodies, political parties, public associations, } \\
\text { enterprises, societies, unions, etc.). }\end{array}$ & $\begin{array}{l}\text { Management: essence, value, } \\
\text { efficiency: educational manual } \\
\text { for universities. - Moscow: } \\
\text { Academical project, Culture, } \\
2006 .\end{array}$ \\
\hline 5 & $\begin{array}{l}\text { R. } \\
\text { Nurmukhametova, } \\
\text { B. Moldagaliyev, } \\
\text { etc. }\end{array}$ & $\begin{array}{l}\text { Group of activities: process of planning, } \\
\text { organization, control, motivation and analysis of } \\
\text { its results. }\end{array}$ & $\begin{array}{l}\text { Pedagogy. Dictionary. - Aktau, } \\
\text { 2010. - p. } 13 .\end{array}$ \\
\hline 6 & $\begin{array}{l}\text { E.A. Konyayeva, } \\
\text { L.N. Pavlova }\end{array}$ & $\begin{array}{l}\text { System of planning, organization and } \\
\text { management of education management. }\end{array}$ & $\begin{array}{l}\text { Brief dictionary of pedagogical } \\
\text { concepts. - Chelyabinsk, 2012. - } \\
\text { p.118. }\end{array}$ \\
\hline 7 & A.M. Novikov & $\begin{array}{l}\text { Element, function of organized systems of } \\
\text { various nature: biological, social, technical, } \\
\text { ensuring preservation of their certain structure, } \\
\text { maintenance of the mode of activity, } \\
\text { implementation of the program, purpose of } \\
\text { activity. }\end{array}$ & $\begin{array}{l}\text { Pedagogy. Dictionary of the } \\
\text { system of basic concepts. - } \\
\text { Moscow, 2013. - p. } 227 .\end{array}$ \\
\hline 8 & $\begin{array}{l}\text { Z. Suleymenova, } \\
\text { M. Koshanova }\end{array}$ & $\begin{array}{l}\text { Conscious regulation of psychological, } \\
\text { organizational and methodical processes and } \\
\text { relationships in the school. }\end{array}$ & $\begin{array}{l}\text { Dictionary of psychological- } \\
\text { pedagogical terms. Kokshetau, } \\
\text { 2014. p. } 9 \text {. }\end{array}$ \\
\hline & \multicolumn{3}{|c|}{ Managerial competency } \\
\hline 9 & T.I. Shamova & $\begin{array}{l}\text { Integration of the complex of managerial } \\
\text { knowledge, skills and social experience, } \\
\text { personal qualities, creative focus on achieving } \\
\text { personally and socially significant pedagogical } \\
\text { results. }\end{array}$ & $\begin{array}{l}\text { Intra-school management: } \\
\text { issues of theory and practice. - } \\
\text { M.: } 1991 .\end{array}$ \\
\hline 10 & $\begin{array}{l}\text { M.I. Marin, I.V. } \\
\text { Ivanikhin and S.I. } \\
\text { Lonchak }\end{array}$ & $\begin{array}{l}\text { The system of internal resources necessary for } \\
\text { organizing effective leadership of students in } \\
\text { accordance with all components of the } \\
\text { pedagogue's activities (goals, principles, } \\
\text { content, technologies, etc.). }\end{array}$ & $\begin{array}{l}\text { Evaluation of managerial } \\
\text { competence of management } \\
\text { personnel of SFS (the State Fire } \\
\text { Service): Methodological } \\
\text { manual. - M.: 1998. - p. } 10 .\end{array}$ \\
\hline 11 & $\begin{array}{l}\text { O.Yu. } \\
\text { Zaslavskaya }\end{array}$ & $\begin{array}{l}\text { As the specific ability, necessary for the } \\
\text { implementation of the effective educational } \\
\text { process in the concrete subject area and } \\
\text { including highly specialized knowledge, special }\end{array}$ & $\begin{array}{l}\text { Development of managerial } \\
\text { competence of the teacher in } \\
\text { the system of multilevel training } \\
\text { in the field of teaching } \\
\text { methodology of computer }\end{array}$ \\
\hline
\end{tabular}




\begin{tabular}{|l|l|l|l|}
\hline & & $\begin{array}{l}\text { kind of subject skills, ways of thinking, as well } \\
\text { as responsibility for own actions. }\end{array}$ & $\begin{array}{l}\text { science: Dissertation abstract of } \\
\text { Doctor of Pedagogical Sciences. } \\
- \text { M.: 2008. - p. 3. }\end{array}$ \\
\hline 12 & N.P. Shamina & $\begin{array}{l}\text { Integrative unity of the functional and personal } \\
\text { components, providing realization of of } \\
\text { managerial functions and personal qualities for } \\
\text { the purpose of training, upbringing and } \\
\text { development of all subjects of educational } \\
\text { process at the elementary school. }\end{array}$ & $\begin{array}{l}\text { Formerial } \\
\text { compence of the future } \\
\text { pedagogue of elementary } \\
\text { school: Dissertation abstract of } \\
\text { Candidate of Pedagogical } \\
\text { Sciences. - Samara, 2013. - 24 } \\
\text { p. }\end{array}$ \\
\hline 13 & V.E. Malgin & $\begin{array}{l}\text { The development of managerial competence } \\
\text { contributes to the process of continuous } \\
\text { acquisition and renewal of professional } \\
\text { knowledge, which, in turn, is possible through } \\
\text { the system of advanced training and qualifying } \\
\text { evaluation of the leader. }\end{array}$ & $\begin{array}{l}\text { Problems and prospects of the } \\
\text { education development. }\end{array}$ \\
$\begin{array}{l}\text { Article: "Development of } \\
\text { managerial competence of the } \\
\text { head of sports school" } \\
\text { Date of publication: February 24, } \\
2014\end{array}$ \\
\hline
\end{tabular}

Thus, management in the broad sense means the general function of organizational systems (biological, technical, social, pedagogical, etc.).

Summarizing the data from the table, we can say that the managerial competence of the pedagogue consists of functional, methodological and personal components. Therefore, the content of pedagogical activity is determined by professional competences, i.e. the level of readiness and realization of the pedagogue to the profession; the content of pedagogical management is determined by the components constituting competence. It follows from this that the content of pedagogical activity is the notionally unchanged component of the profession; content of pedagogical management is determined by a set of components of managerial competence, which can be depended on each other in different degree and can be in different level of demand at realization of the specified competence.

\section{DISCUSSION}

We tried to present the results of the ascertaining experiment in the following Figure 1.

As it was shown from the diagram, West-Kazakhstan Innovative-Technological University has the following indicators: the scale of assessment of communicative abilities -0.52 points; the scale of assessment of organizational abilities -0.54 points.

The assessment scales of Kazakh Academy of Sport and Tourism represent the following: communicative abilities - 0.58 points; organizational abilities -0.46 points.

The comparative analysis of the results of two universities was presented in Tables 2 and 3. 


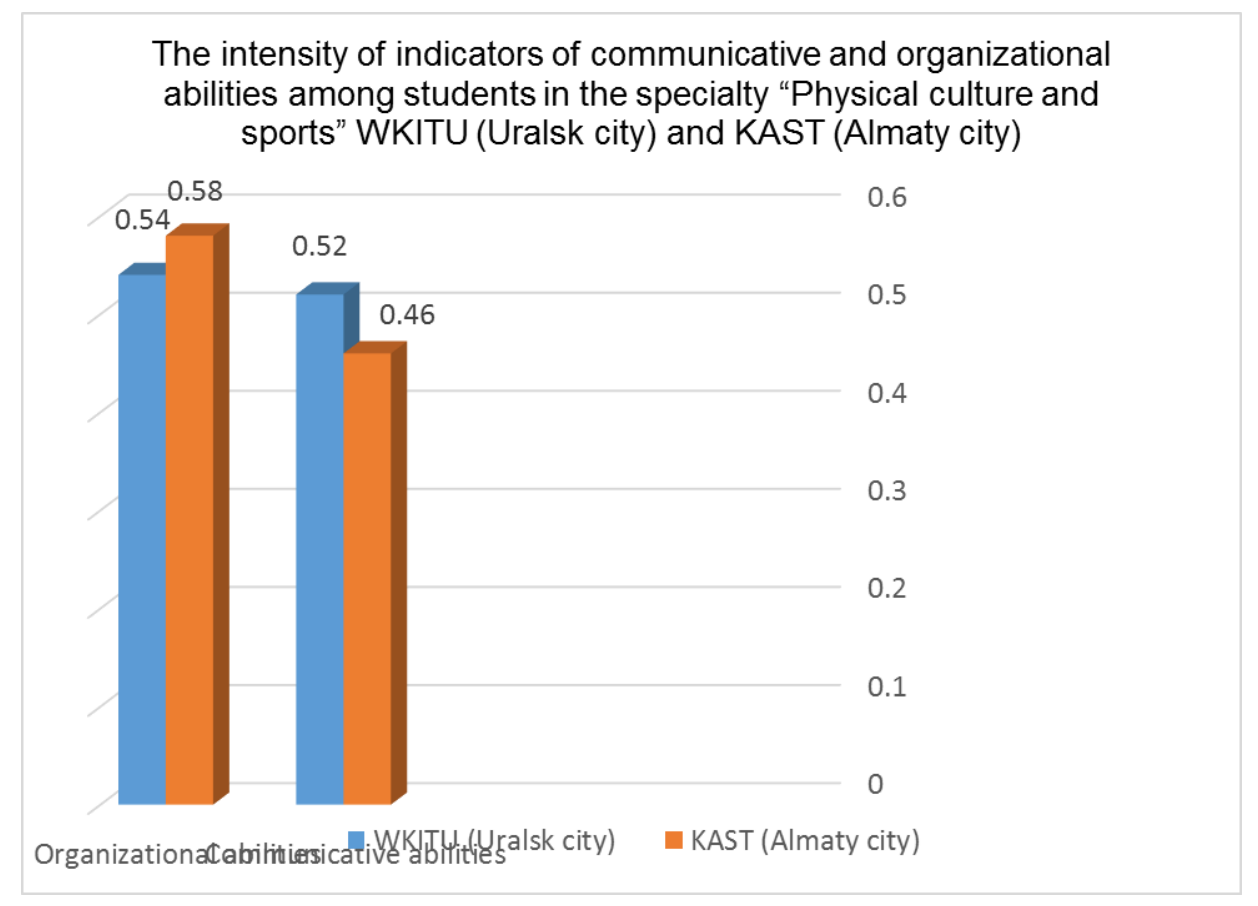

Figure 1. Results of the ascertaining experiment according to the "Methodology for assessing the communicative and organizational abilities of the personality" (V. Sinyavsky, B.A. Fedorishin)

Table 2. Level of manifestation of communicative abilities of students.

\begin{tabular}{|l|l|l|l|}
\hline $\begin{array}{l}\text { Level of manifestation } \\
\text { of communicative } \\
\text { abilities }\end{array}$ & Scales & $\begin{array}{l}\text { West-Kazakhstan } \\
\text { Innovative-Technological } \\
\text { University (Uralsk city) }\end{array}$ & $\begin{array}{l}\text { Kazakh Academy of Sport } \\
\text { and Tourism (Almaty city) }\end{array}$ \\
\hline Low & $0.10-0.45$ & & \\
\hline Below the average & $0.45-0.55$ & 0.52 & 0.46 \\
\hline Average & $0.56-0.65$ & & \\
\hline High & $0.66-0.75$ & & \\
\hline
\end{tabular}

Table 3. Level of manifestation of organizational abilities of students.

\begin{tabular}{|l|l|l|l|}
\hline $\begin{array}{l}\text { Level of manifestation } \\
\text { of organizational } \\
\text { abilities }\end{array}$ & Scales & $\begin{array}{l}\text { West-Kazakhstan } \\
\text { Innovative-Technological } \\
\text { University (Uralsk city) }\end{array}$ & $\begin{array}{l}\text { Kazakh Academy of Sport } \\
\text { and Tourism (Almaty city) }\end{array}$ \\
\hline Low & $0.20-0.55$ & & \\
\hline Below the average & $0.56-0.65$ & 0.54 & 0.58 \\
\hline Average & $0.66-0.70$ & & \\
\hline High & $0.71-0.80$ & & \\
\hline
\end{tabular}

Based on the figure, we can draw the following conclusion that the majority of subjects showed the level from 0.48 to 0.58 points, i.e. such students, who received the rating of "2" $(Q=2)$, have the development of communicative and organizational inclinations at the level below the average. They do not seek communication, feel constrained in the new company, collective, prefer to spend time alone with themselves, limit their acquaintances, have difficulties in establishing contacts with people and in speaking to the audience; they are poorly oriented in the unfamiliar situation, do not defend their opinion, they are hard to 
experience resentment. The manifestation of the initiative in social activities is extremely underestimated, in many cases they prefer to avoid making independent decisions.

A special study of the essence, content and level of managerial competence of active specialists in physical culture and sports, taking into account the specifics of their profile, as well as the identification of general peculiarities of managerial competence, allows to offer sports education the new guideline and criteria for training of future specialists.

\section{FINDINGS}

The research showed that the particular importance has communicative aspect in managerial competence of specialists in physical culture and sports. The success of communicative activity is determined by the chosen style of leadership and correct understanding of the criteria of efficiency of communicative and educational activity. The results of the ascertaining experiment showed that the process of formation of managerial competence at future pedagogues of physical culture corresponds to the level below the average. Proceeding from the showed results, it is obvious carrying out the certain systematic work on the formation of managerial competence among future specialists.

\section{CONCLUSION}

Thus, summarizing the above-stated, there can be suggested the following methodological recommendations:

- In order to increase the level of managerial competence of students - future teachers, it is necessary to use systematically the diagnostic methods for determination of their level of managerial competence and its dynamics during the last courses of training and promptly make corrections into the educational-educative process taking into account the obtained data;

- It is necessary to deepen the inter-subject integration in the training process of students, both between theoretical disciplines of the curriculum and between theoretical and practical courses. Interdisciplinary special courses, such as social-psychological issues of management, management philosophy, pedagogical management, etc. may contribute to this;

- In order to strengthen the vocational-pedagogical directivity of students, it is necessary to rework the existing and introduce new elective courses on vocational-pedagogical competence, basics of management, professional self-education.

\section{REFERENCES}

Ackerman, L. D. (1984). The psychology of corporation: How identity influences business. The Journal of business strategy, 5(1), 56. https://doi.org/10.1108/eb039047

Afanasyev, V. G. (1973). About system approach in social knowledge. Questions of philosophy, 6, 98111.

Albrecht, K., \& Zemke, R. (1985). Service America!. Dow Jones-Irwin.

Blake, R., \& Mouton, J. (1964). The managerial grid: The key to leadership excellence. Houston: Gulf Publishing Co, 350.

Lee, Y. (1991). Manager's career. Translated from English M.: "Progress," p. 384.

Lomov, B. F., Kitov, A. I., \& Rubakhin, V. F. (1977). Actual problems of management psychology.

Pavlova, L. N. (2008). Theory and practice of pedagogical management of development of school children's collective: monograph. Chelyabinsk: "Education" Publishing House. 
Sulpovar, L. B., \& Mazayeva, N. P. (1996). Basics of personnel management. Edited by T.V. Rosarenova. State Academy of Domestic Sphere and Services, $172 \mathrm{p}$.

Woodcock, M., \& Francis, D. (1991). Liberated Manager. For head-practice. M.: The Case.

Zhuravlev, A. L. (2002). About the modern state of domestic management psychology in the context of its history. Modern problems of management psychology. Institute of Psychology of the Russian Academy of Sciences, 6-17.

\section{(c) $(\mathrm{B})(\mathrm{EY}$}

This work is licensed under a Attribution-NonCommercial-NoDerivatives 4.0 International (CC BY-NC-ND 4.0). 